\title{
The Role of Startups in Digitalization and Innovative Develop- ment of Economy
}

\author{
Olga Nikolaevna Likhacheva ${ }^{1 *}$, Lelya Germanovna Pashtova ${ }^{1}$, Liubov Alexandrovna Setchenkova ${ }^{1}$, Tatiana Ale- \\ xandrovna Slepneva ${ }^{1}$ \\ ${ }^{I}$ Financial University under the Government of the Russian Federation, Leningradsky prospect, 49, Moscow, 125993, Russia \\ *Corresponding author E-mail: likhacheva.o.n@mail.ru
}

\begin{abstract}
The article examines the potential of introduction of new digital technologies in the Russian market through the development of startups in the modern economy. The article considers the key drivers of growth of digital startups and the prospects for their development in the domestic market of Russia and establishes the role of progressively developing information sphere for the investments of venture units of large corporations, business angels, the largest investment funds and other investors in the world economy. The peculiarities of startups' development in the Russian economy in modern conditions are revealed and the most significant solutions of this problem are presented.
\end{abstract}

Keywords: Digital platforms; Innovation; Technological development; The Russian economy; Startups

\section{Introduction}

At present, the innovative way of development is one of the most important and urgent problems for many countries, including Russia. Venture investment is one of the most effective instruments of innovation funding in the world practice. In Russia, at the moment, the venture investment market is at the initial stage of development, but at the same time, the state annually implements measures to develop the industry. Under new conditions of changes in economic development, it is important for Russia to support companies (greenfields, startups) doing their business effectively that will be able to increase innovative activity in the domestic market.

The innovative development of Russia's economy today is possible on the basis of the activation of the development of startups against the background of general growth of industrial production and anticipated structural reorganization of production sector. Russia's losing profit because of innovation lagging makes up USD 1.214 bln a year (Interfax - Economic Analysis Center). In developed economies, $75-90 \%$ of GDP growth is provided by the growth of innovation sector, in Russia it accounts for $10 \%$, which negatively affects the overall efficiency of the economy [1].

\section{The Overview of Digital Technologies Mar- ket}

The expansion of importance of startups, greenfields, and small business in the Russian economy is currently very important. A set of tools, jointly called "Industry 4.0", includes various innovative technologies, such as big data technology, distributed ledger technology, remote identification technology (machine vision), machine learning technology (artificial intelligence), open interfaces technology, digital processes technology, industrial Internet of things, virtual and augmented reality, unmanned aerial vehicles and robotics, three-dimensional modeling, etc.
These technologies are already transforming our lives. For example, digital process technologies allow the money transfer processes to be automated and the effectiveness of processes to be increased at maximum due to the significant reduction of manual labor rate. The remote identification technologies allow the level of reliability when making decisions about the use of electronic means of payment by an appropriate user to be increased significantly by using biometric technologies as well. The remote service technologies allow the availability of payment services to be increased significantly and the payment services to be provided to the population of the Russian Federation in 24/7 mode. As early as a year ago, an explosive growth in big data and machine learning sphere was actively predicted, but one could hardly imagine the boom to be so loud. The main drivers in this area are chat bots, global automation of intellectual work (the consulting, support, and analysis of user behavior), and various optimization technologies.

Whereas the demand for big data software and services is currently growing by more than $18 \%$ per year, it is estimated by experts that in future the growth will accelerate, because the total amount of digital data will increase from 16.1 zettabytes in 2017 up to 163 zettabytes in 2025 [2].

The full-scale introduction of these innovative technologies into the world economy in future may have an effect on productivity and labor market being comparable to the industrial revolutions of the past. Thus, for the global economy the anticipated annual effect of introducing the Internet of things may amount to USD 4 th - USD 11 tln by 2025 [3] (Figure 1) 


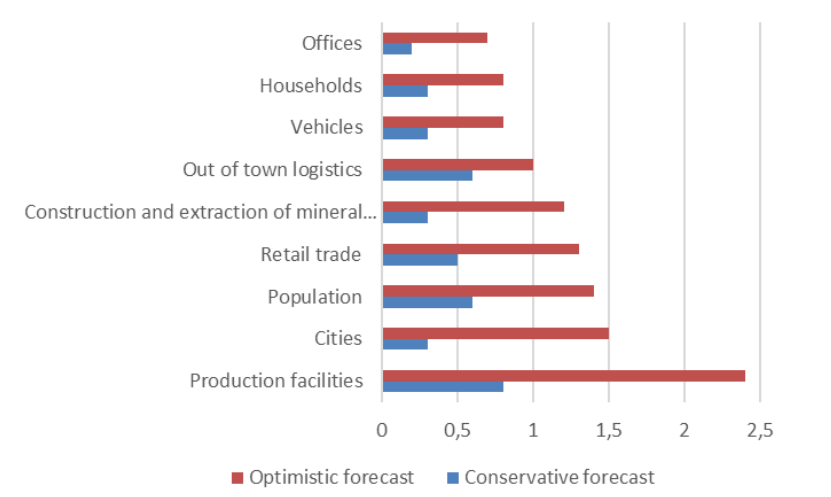

Fig. 1: The contribution of the Internet of things to the global economy Source: developed by the authors on the basis of [4] data.

As for Russia, the positive dynamics of startups in the area of the Internet of things is also expected in 2018. A great number of different initiatives aimed at the improvement of users' lives was launched by large business and the state due to such solutions. Investors rest their major hopes in the segment of housing and communal services. Some projects in the sphere of digital medicine and logistics appeared as well (taking into account the fact that in Russia the law on telemedicine is planned to be adopted in the nearest future, the services for remote consultation with doctors are expected to appear in the market soon). In Russia a digital HR trend has emerged: according to various estimates, this market may be up to $\$ 20$ bln per year.

In 2017, Internet services and mobile applications being based on the transfer of offline businesses into online ones account for about $20 \%$ of investment-attractive projects. Due to the fact that many businesses are switching to online mode, a lot of marketing services for automation and attracting new users appear on the market [5].

Companies that can use all the key levers of value creation by means of technology will have a stable competitive advantage and will be able to strengthen their positions both in domestic markets and internationally.

\section{The Analysis of Launching and Financing of Startups in Russia and in the World}

A startup (start-up) is an innovative company with a short start-up period and the prospect of earning high profits for the project initiator and investors. It is characterized by the novelty of idea, the promptness of implementation, and increased risks.

There are several signs that allow an investment project to be considered a startup:

- an innovative idea: it is based on the need to improve something in order to change people's lives qualitatively, to create a new useful product;

- the promptness of creation: only those projects are traditionally considered to be startups, the launch of which takes 8 months maximum. If during the said time they do not make profit, they are closed. In Russia, the implementation may last up to 2-3 years;

- the young age of initiators of the innovation;

- high risk: about $70 \%$ of innovative projects is wound up in the first year, $10-15 \%$ more do not live until 2 years. According to pessimistic estimates, only 1 startup among 10 ones becomes a business and brings a stable income;

- aim: the sale of a startup to a large company or the promotion of a project to generate high profits from the implementation of the idea;

- the presence of like-minded people who help to develop the idea and maintain interest in it, for example, business angels [6].

The reasons for the growth of digital startups:
- the exponential growth of Internet users (Figure 2), which allows the access to the global market to billions of people to be obtained;

- the growth of social networks;

- a greater (significant) coverage of the market with smartphones, allowing a quick access to the Internet to be obtained;

- the low cost of development of applications and software (that previously only large companies could afford).

$4,000,000,000$

$3,000,000,000$

$2,000,000,000$

$1,000,000,000$

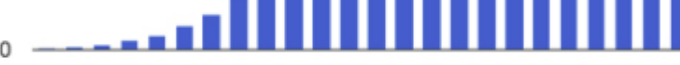

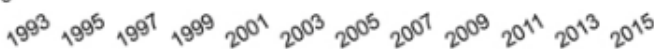

Fig. 2: The number of Internet users in the world, men. Source: developed by the authors on the basis of [7] data

Annually not only in Russia, but also in the whole world, a large number of innovative startup companies can start their activities. However, only 2-3 out of 10 launched startups succeed. The analysis of the American experience of venture entrepreneurship allowed making the conclusion that the period of formation and maturation of small innovative firms continues for 5-7 years on average, then about $20 \%$ of small firms is transformed into open corporations, $60 \%$ of firms is absorbed by more powerful competitors, and $20 \%$ of them become bankrupt [8]. In the Russian Federation, only $10-15 \%$ of the total number of the Russian startups can be called successful [9].

The main problem upon launching a startup is its financing. Thus, the most significant expense item when launching a startup is $R$ \& D. This stage appeared to be the most burdensome for all segments of startups, except for the "energy efficiency" segment, where raw materials and materials account for the largest share in the cost structure $(49.4 \%$ versus $22.9 \%$ for research and development). The largest share of the cost of equipment in total costs when launching a startup was recorded in industrial startups: the share of equipment costs was $29.5 \%$ [10].

Thanks to the advent of the venture financing mechanism for innovation in the United States, a large number of leading companies in the world appeared on Fortune 500 list of 2016, among which there are Apple, Intel, Microsoft, Amazon.com, Google, eBay, Yahoo [11]. The positive impact of venture capital on the economy can be traced by the macroeconomic indicators of China, where pre-crisis growth rates of the venture investment market were $257.92 \%$. In general, the positive experience of foreign countries demonstrates the need for the development of the domestic market, since at present venture capital is the only effective source for financing innovative activities, the development of which directly affects the growth and competitiveness of the country's economy.

\section{The Analysis of Startups in Russia and in the World by Segments}

The conservatism of investors in the Russian market should be noted, as evidenced by the distribution of investment by segments. The main share of investments by segments in the Russian Federation falls on telecommunications $(37.08 \%)$, consumer sector 
$(11.32 \%)$ and financial sector $(33.78 \%)$. While in the United States, the main share of investments falls on software $(18 \%)$, biotechnology (17\%), industry and energy (16\%), medical services and equipment (10\%) [12]. In comparison with the Chinese venture capital market, some similarity in the reluctance to bear the increased risks is worth mentioning. The peculiarities also include a large number of projects, a significant amount of highly qualified personnel, the non-orientation of most projects for export, the lack of information infrastructure, the lack of legislative base, the reduction in the number of organizations and the number of personnel involved in research and development. The main source of funding for research and development is budgetary funds (65\%). The United States occupies a leading position in terms of venture investment and the number of projects implemented. In the USA, venture business is concentrated in the most knowledge-intensive segments. First of all, attention is paid to biotechnologies, which are most popular. Also preference is given to business services and production of food products, industry, medicine, software, telecommunications. It is in these sectors that venture capital is invested most of all (Table 1). There is a tangible trend of growth in the dynamics of venture capital investments, which can be traced from the very beginning of the venture business in the United States. The amount of venture capital invested in the company is actively growing annually.

Table 1: The number of funds invested in the most priority segments in the USA, mln. USD

\begin{tabular}{|c|c|c|c|}
\hline Segment & $\mathbf{2 0 1 4}$ & $\mathbf{2 0 1 5}$ & $\mathbf{2 0 1 6}$ \\
\hline Biotechnologies & 3722.6 & 3866.6 & 4733.5 \\
\hline Business services and products & 293.8 & 453.4 & 234.8 \\
\hline Industry & 2640.2 & 3389.9 & 3516.8 \\
\hline Medical equipment and accessories & 2575.1 & 2347.9 & 2806.7 \\
\hline Software & 3662.2 & 4855.8 & 6714.4 \\
\hline Telecommunications & 528.5 & 837.6 & 677.9 \\
\hline
\end{tabular}

Source: developed by the authors on the basis of [13] data

In the Russian market, investor preferences are concentrated on sectors directly dependent on consumer demand. Leaders in attracting venture capital funds have become sectors that cover the financial and consumer market, information and communication technologies. The Russian venture financing market differs in the direction of financing, that is the choice of sectors where funds are invested. The reason for this is the unwillingness to take risks by investing in projects with a high degree of uncertainty, and projects with a long payback period (more than 3-5 years). The imperfect legislation does not allow developing the venture business in full, and that is a distinctive feature too.

In Russia, the climate for the development of digital startups is unfavorable. This is clearly manifested in the fact that in recent years such companies are in minority. However, large respectable companies can perform innovative activities as well. Thus, in Russia, the work on the development of technological innovation and the achievement of leading positions in the field of technology can be carried out by the following types of companies:

1) a long-standing organization in the market (for example, Sberbank), which implement large-scale programs in the development and implementation of innovations and set the tone for their segments;

2) former startups and small firms that have grown into large companies that are at the forefront of technology development. An example is Tinkoff Bank, being focused on the development of a simple, intuitive digital financial platform, which completely refused from using physical offices [14].

Russia can expand the circle of digital leaders from among the large traditional companies, and also strengthen those few startups that managed properly develop in the market. On the other hand, to be among the world leaders, it is important to improve the conditions for the operation of new technological startups. At the moment, if we measure the business of leading Russian digital companies by the global scale, their progress looks moderate (Figure 3). This concerns both the number of successful digital startups and companies in Russia and their turnover.
The largest Russian public companies in the sector of information and communication technologies (ICT) account for less than $1 \%$ of the revenue of thousands of the world's largest information technology companies. About 60 startups from the USA are registered every day while in Russia on average 1,2 startups are registered daily, and that roughly corresponds to the speed of the emergence of new startups in the countries of the Middle East [3].

\section{Share in the revenue of 1000 largest public ICT}

companies, \%

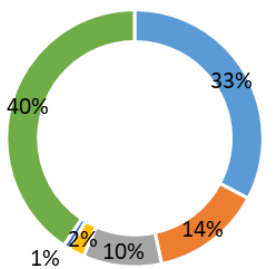

- USA $\|$ Europe $\|$ China $=$ India $\|$ Russia $\|$ The rest of the world Fig. 3: Analysis of two key indicators of the development of the Russian digital segment

Source: developed by the authors on the basis of [13] data

The process of evaluating adult companies is fairly simple, although subjective to some extent. When determining the value of a company, investors primarily consider the market capitalization and multiplier of sales. The evaluation of the cost of startups at an early stage is different. For example, the Berkus method is used to estimate the potential of a startup using empirical indicators. First, the cost of reproduction of the startup is calculated, i.e. costs for licensing, patenting, cost of specialists, etc. Then, to this "base" are increased interest on the most effective indicators of the startup [15]:

- the attractiveness of idea (20- $40 \%)$;

- the quality and effectiveness of management (20-80\%);

- the professionalism of the team (10- $40 \%$ );

- innovativeness (10-20\%);

- a readymade prototype (20-40\%);

- a cashflow (20- $40 \%)$.

Like any empirical assessment, the method is characterized by personal bias and an attempt to adjust to the current market moment.

While assessing startups, one can calculate the following indicators:

- the average index of the cost of startup launching;

- the index of the cost of startup launching depending on the segment;

- the index of the cost of launching of startups being engaged in certain programs and projects.

The average index of the cost of startup launching is calculated by the following formula:

$I s z=\frac{\sum_{i=1}^{n} p}{n}$,

where $\mathrm{p}$ is the cost of launching of a project; $\mathrm{n}$ is the number of startups being referred to all analyzed segments.

The index of the cost of launching of startups in a segment is calculated by the following formula:

Isz segm $=\frac{\sum_{i=1}^{n} p \text { segm }}{n}$,

where $p$ is the cost of launching of one project in the segment; $n$ is the number of startups in the segment. 
The index of the cost of launching of projects (the Russian Venture Company, Skolkovo, etc.) is calculated by the following formula:

$$
\boldsymbol{I r v k}=\frac{\sum_{i=1}^{n} \boldsymbol{p} \boldsymbol{r v} \boldsymbol{k}}{\boldsymbol{n}}
$$

where $p$ is the cost of launching of one project being engaged in programs (projects) of the institutional investor; $n$ is the number of startups being engaged in programs (projects) of the institutional investor.

The analysis of the acceptability of the venture project should be based on a comprehensive assessment of its effectiveness, which includes three stages.

At the first stage of the assessment, generally accepted indicators of the effectiveness of investment projects are used: the accounting rate of return (ARR / ROI), net present value (NPV), the payback period (PP, DPP), the profitability index (PI), the internal rate of return (IRR), the modified internal rate of return (MIRR). For an accurate comprehensive grounding of the effectiveness of investment in innovation, it is advisable to use all the listed indicators in the system due to the fact that each of them has distinctive advantages and disadvantages. At the second stage, three main classical approaches can be used to assess intellectual property and intangible assets: the cost approach, the market approach and the income approach. In terms of valuation of a venture project, it is advisable to use a revenue approach based on determining expected revenues, building calculations based on forecast data using DCF methods, direct capitalization, rapid assessment, excess profit, calculation of royalty, expert method. The third stage suggests the application of various methods of modeling and measuring of the cash flows of the proposed venture investments taking into account the impact of risk factors on the implementation of the venture project.

In today's world, the most common way to assess project risks associated with the implementation of venture projects is the use of a specialized approach developed by Standard \& Poor's. This approach is based on a comprehensive analysis of risks associated with technological, production and legal aspects of the enterprise. The total volume of these risks, however, does not fully reflect the current trends, and it is necessary to supplement the methodology for risk assessment with additional risks which are innovative risks, organizational risks, environmental risks, which will contribute to a broader but at the same time more accurate analysis of project implementation risks. All of these, in aggregate, will allow avoiding wrong decisions made by venture companies for project implementation. The determination of cumulative risk of a venture project (Rc) lies in the calculation of the sum of project, systematic and force majeure risk assessments, the weights of which are determined using the expert estimation method, using the following formula [16]:

$$
R c=q 1 * R n+q 2 * R s+q 3 * R u
$$

where $\mathrm{R} c$ is the cumulative risk of a project; $\mathrm{q} 1, \mathrm{q} 2, \mathrm{q} 3$ are the weights of the project, the systematic and the force majeure risk, correspondingly; $\mathrm{R} n$ is the project risk assessment; $\mathrm{R} s$ is the systematic risk assessment; $\mathrm{R} u$ is the force majeure risk assessment. The presented complex methodology of the assessment of the economic efficiency and project risk of joining a venture project allows making more grounded decisions when investing in risky and high-yield innovative enterprises.

\section{The Problems of Startups Launching in Russia}

The development of the technological ecosystem and the venture market in Russia is hindered by two groups of factors. The first one is related to the specifics of the sector. Thus, for example, the required competencies are lacking drastically - both the entrepreneurs' competencies required for building up a high-tech business competently, and the mentors' and investors' competencies required for directing such initiatives and being ready to support them. Entrepreneurs frequently cannot formulate KPI (key performance indicators) of a startup.

The second group of factors is related to the provision of financing in general: the growth of startups is constrained by the low level of development of the country's financial system, in general, and its venture segment in particular.

According to the experts' estimates, the coefficient of expansion of entrepreneurship in Russia in 2012 was 2.68, which means that 2.68 new enterprises were created per 1 closed business. The average age of a successful startup in IT is 20 years, it makes up 35 years in the field of resistance of materials and 53 years in the field of biotechnology [10].

In terms of funding, the domestic technological startups are much inferior to their Western analogues: for example, the median amount of funds raised at the scaling stage in 2013 was $\$ 2.9 \mathrm{mln}$ in the USA, $\$ 2.0 \mathrm{mln}$ in China, and $\$ 4.5 \mathrm{mln}$ in Israel. The structure of funding sources is shifted towards own funds and funds of friends and acquaintances, and such institutions as banks, venture funds, business angels or accelerators are involved slightly.

Currently, there is a large number of corporate funds on the market that unite many small organizations and companies that are active in the field of innovative technologies. The unification of diverse companies enables corporate funds to minimize possible risks by diversifying investment interests. there are a large number of corporate funds on the market that unite many small organizations and companies that are active in the field of innovative technologies. The unification of diverse companies enables corporate funds to minimize possible risks by diversifying investment interests. The most active venture funds in Russia are as follows: Altair Capital, Almaz Capital, Runa Capital, TMT Investments, IIDF, Flint Capital, Maxfield Capital, ImpulseVC.

One of main limitations of the development of domestic innovative companies is the lack of investment resources. And if the amount of state funding for research and development (R \& D) in Russia corresponds to the level of developed countries, amounting to $0.4 \%$ of GDP, the share of private funding for research and development is only $0.7 \%$ of Russian GDP, which is significantly less than in the USA $(1.9 \%)$ or Germany $(2.0 \%)$ [17].

The area of venture financing can be called problematic. Suffice it to say that in the United States the share of its volumes as a percentage of GDP is 21 times greater than in Russia [18]. Its volume in Russia is declining, and the rate of this decline in recent years exceeded $5 \%$ per year. Thus, today, it's unfortunately idle to expect for significant private financing of high-tech startups, being sufficient for the breakthrough development of the sector, and the state funds are sufficient only to keep the market "afloat", but the ones are absolutely not enough to bring it to a fundamentally different level of development.

There is a number of serious problems in the implementation of startups in the Russian Federation. One of them is the lack of financing of startups at the initial stage, especially for high-tech companies being not information technology startups. The amount of grants and cash provided to startups is very small and limited. State institutions are not ready to provide initial financial support to startups in the Russian Federation.

It is also necessary to pay attention to such a problem as low demand for innovative solutions on the part of the largest companies that finance the purchase of equipment under the guise of "nanotechnologies".

In addition, the lack of original ideas prevents the Russian startups from the development since the projects of Russian startups are foreign analogs in general.

Another problem is the lack of unified requirements for innovative projects, the norms of an innovative and venture ecosystem, an 
objective assessment of the investment attractiveness of innovative investment. Thus, for example, the typical cases in the evaluation of the effectiveness of innovative projects in venture financing are difference in the interpretation of analysis results depending on the stage of evolution of the innovation company, differences in the selection of evaluation indicators from the goals and objectives of investors, and the specific features of each branch of the economy [19].

\section{Proposals for Optimizing the Launching and Development of Startups in Russia}

In order to achieve a significant improvement in the situation and to ensure positive sector dynamics, the joint efforts of all the key players of the process namely the state, the private investors and the organizers of startups themselves are required.

In particular, the governmental authorities can take the following actions to stimulate the development of the Russian digital startups and to improve the investment climate:

1.To simplify the access to participation in competitive selection of projects and venture financing in the regions of Russia - to create the required infrastructure there and to provide equal conditions for applicants (according to the RAVI, 83\% of the volume of venture investments for 2016 was for the companies located in the Central Federal District).

2.To increase the efficiency of selection of startups and to redistribute the budget load - to create a well-established multi-level system of project financing (for example, the selection and funding from the corresponding budget at the city, the regional and the federal levels).

3.To create conditions for retaining qualified specialists and business in the country as well as for attracting foreign investors to Russia: to implement an effective system of intellectual property protection, to simplify the visa regime for investors and qualified specialists, and to develop a network of accelerators, business incubators and special economic zones, working in close partnership with large business on preferential terms under the state support programs, throughout the country.

4.To use the levers of influence over large companies more efficiently as well as to consider possible mechanisms of additiona tax incentives to stimulate the demand for innovation on their part. 5.To facilitate the attraction of direct private investment through crowdfunding platforms, in particular, to create a regulatory and legal framework for the operation of such sites.

6.To open virtual reception centers and other contact centers of government authorities in order to advise innovative companies on the issues of methodological and regulatory support of their activities, and the protection of consumers' and investors' rights.

7.The state bodies should develop legislative drafts "On Digital Financial Assets", "On Alternative Methods of Attracting Investments (Crowdfunding)", "On the Amendment of Part One, Part Two and Part Four of the Civil Code of the Russian Federation" (the so-called legislative draft legislative "On Digital Rights").

8.To develop and to adopt the legislative acts aimed at the support and development of digital startups, including the provision of tax and other benefits.

For simultaneous solving of such problems as the shortage of funding and the correct choice of a startup, investing in which is most expedient, it makes sense for private investors to organize joint work with other state and private investors. As a model for such cooperation, one can use the experience of the Internet Initiatives Development Fund (IIDF) in the creation and improvement of partner accelerators with the leading Russian IT companies. Startup organizers can be recommended to pay increased attention to the selection of partners and to provide for time and material resources required for this. A right partner can not only provide the necessary funding, but also provide the startup with expert support. On this basis, it is preferable to deal with a strategic in- vestor who possesses the special knowledge being required and who is interested in a long-term cooperation.

In Russia, there is a considerable intellectual potential for the future development of digital startups: in the country, there are many qualified developers, being in demand in the Silicon Valley as well and having experience in participating in foreign projects. The key, which will release this potential, may become a competent organization of the support of digital startups from the state and private investors as well as an adequate funding. Despite the fact that the current macroeconomic situation imposes certain restrictions, we assess the prospects for the development of the venture capital market in Russia with restrained optimism, which is based on a significant scale of unused potential. An essential condition of the success of its implementation will be the absence of new external shocks.

It should be noted that in the financial sphere such a positive trend has emerged as large banks' creating their own venture funds to finance small enterprises in the sphere of high technologies. Such funds have already been opened by Sberbank, VTB, Alfa Bank and the others. The development of state development institutions, which help small business with investments, is being continued.

\section{Conclusion}

While investigating the reasons for the weak development of innovative startups, one can note the following ones in Russia:

Firstly, the Russian venture market is very young in comparison with Western countries: according to the estimates of the Russian Venture Company and the Russian Venture Capital Association (RVC, RVCA, 2014), the aggregate capital of all Russian venture funds (which invest in technological start-ups) is USD 30,3 bln, and the total investment for the first three quarters of 2014 was as little as USD $0.63 \mathrm{bln}$.

Secondly, Russia has a very short planning horizon, being up to 3 years, this is why long-term production startups are not attractive to investors yet.

Thirdly, there is a difficult access to financial resources, unfavorable economic conditions, administrative barriers, instability of property relations and corruption.

Moreover, the fourth problem, being the most important one, in our opinion, is a low-quality management in small manufacturing companies. According to the opinion of venture market experts as well as to the research conducted by the RVC, the Bortnik Fund and other development institutions, a company's head's managerial mistakes are the most serious reason of its slow growth or even dissolution.

The most part of the mistakes in the sphere of innovative startups is the controversial regulation of relations between the founders or between the founders and the executive officers, inconsideration of property rights as well as of intellectual property (from trademarks to patents for inventions and know-how), "nontransparency" of financial statements and payment of salaries to employees. The most important thing is that entrepreneurs do not understand the need to change their own role and their own behavior as the company gets to the new levels of development.

\section{References}

[1] Pashtova L (2014), Innovative activities of Russian companies: problems and prospects. Koncept 4.

[2] Whiting R, The 10 Coolest Big Data Startups Of 2017 (So Far) www.crn.com/slide-shows/applications-os/300088266/the-10coolest-big-data-startups-of-2017-so-far.htm.

[3] World Robotics Industrial Robots, Report, 2016. ifr.org/worldrobotics.

[4] Setchenkova L, Syzonenko I \& Osadchiy N (2018), Problems and prospects of development of digital startups in the modern economy of Russia. Financial life 1, 25-30. 
[5] Koroleva O (2017), Trends of it startups in 2017. vc.ru/20792startup-trends-2017.

[6] Stolypin P (2016), What is startup? moneymakerfactory.ru/spravochnik/startap/

[7] Internetlivestats.com

[8] Krasovskaya O (2014), Venchurnoye finansirovaniye. Moscow: Lambert Academic Publishing.

[9] Limitovsky M (2015), Investitsionnye proekty $i$ realnye optsiony na razvivayushchihsya rynkah. Moscow: Publishing centere Yurayt.

[10] Pashtova L \& Baev G (2015), Current problems of startups (smal industrial enterprises) in the economy Russia. Financial analytics: problems and solutions (economic issues) 37, 26-40.

[11] Fortune (2016), Global 500. http://fortune.com/global500/2016/

[12] Yearbook 2015. National Venture Capital Association; Yearbook 2016. National Venture Capital Association. World Robotics Industrial Robots, Report. ifr.org/worldrobotics.

[13] PricewaterhouseCoopers. www.pwc.com

[14] How much does your country invest in R\&D? http://www.uis.unesco.org/_layouts/unesco/research-anddevelopment-spending/.

[15] Morkovina S \& Kolesnichenko E (2014), Instrumentary otsenki urovnya investitsionnoy privlekatelnosti startapov. Proceedings of the 2014 scientific and practical conference: Effective HRtechnologies and practices in modern Russian companies, 93-120.

[16] Puchkova E \& Ter-Grigoryants A (2016), Instrumentary otsenki effektivnosti venchurnyh proektov. Bulletin of North-Caucasian technological University 4, 199-202.

[17] Data for the Sustainable Development Goals. www.uis.unesco.org/_layouts/unesco/research-and-developmentspending.

[18] OECD, Entrepreneurship at a Glance 2016. 2016. Paris: OECD Publishing.

[19] Gulkin P \& Terebynkina T (2014), Otsenka stoimosti i tsenoobrazovaniye $v$ venchurnom investirovanii $i$ pri vyhode na rynok IPO. Saint Petersburg: Analitic centre Alpari SPb. 